\title{
"Free Press-Fair Trial" Revisited: Defendant-Centered Remedies as a Publicity Policy
}

There is widespread concern that extensive crime reporting in the mass media threatens the right of an accused to a fair trial by influencing the behavior of judges and juries. Several kinds of crime coverage may have this effect: the publication of information and opinions which might be inadmissible as evidence, ${ }^{1}$ the testimony of unsworn witnesses, ${ }^{2}$ the sensational and one-sided presentation of material which would be admissible in court, ${ }^{3}$ and even the extensive reporting of the bare facts of a criminal incident. ${ }^{4}$ No empirical studies, however, have been made to identify the forms of crime coverage most likely to result in prejudice or describe the kinds of criminal proceedings most affected by extensive publicity. The problem posed by crime coverage is almost universally acknowledged, but the focus of recent inquiry has been directed less to the nature of the problem than to the search for appropriate solutions. ${ }^{5}$

This comment will review several measures designed to immunize criminal proceedings from the prejudicial effects of publicity and suggest a system based on automatic relief to defendants as the appropriate next step in limiting the prejudicial effects of extensive coverage of crimes.

1 Courts have usually limited their definition of "prejudicial publicity" to the publication of inadmissible material. E.g., Irvin v. Dowd, 366 U.S. 717 (1961); Marshall v. United States, 360 U.S. 310 (1959). Commentators generally recognize such material to be an important, but not the only, source of publicity prejudice. See generally FeLsHer \& Rosen, The Press in the JuRy Box 35-51 (1966); McCarthy, Fair Trial and Prejudicial Publicity: A Need for Reform, 17 Hastings L.J. 79 (1965); Comment, Fair Trial v. Free Press, 38 SO. CAX. L. REv. 672 (1965).

2 See Sheppard v. Florida, 341 U.S. 50, 52 (1951) (Jackson, J., concurring). See generally Goldfarb, Public Information, Criminal Trials and the Cause Celebre, 36 N.Y.U.L. REv. 810 (1961); C. Jaffe, The Press and the Oppressed-A Study of Prejudicial News Reporting in Criminal Cases (pts. 1-2), 56 J. CRIM. L., C. \& P.S. 1, 158 (1965).

3 Comment, Controlling Press and Radio Influence on Trials, 63 HaRv. L. Rev. 840, 841 (1950); see Comment, supra note 1, 38 So. CAL. L. REv. at 681 .

4 Felsher \& ROSEN, op. cit. supra note 1, at 174-87 (effects upon public opinion of a typical style of extensive crime reporting).

5 E.g., Goldfarb, supra note 2; C. Jaffe, supra note 2; L. Jaffe, Trial by Nezspaper, 40 N.Y.U.L. REv. 504 (1965). 


\section{Present Treatment of the Problem}

It is frequently asserted that "the best answer to the crime coverage problem would be the answer of self-discipline." 6 The police and the organized bar could prohibit their members from releasing information which might be prejudicial if publicized, and voluntary restraints by the press would solve the problem. However, although a number of voluntary codes have been drafted and several adopted, ${ }^{7}$ very few have been observed with any consistency. Voluntary restraint has failed in the big cities. ${ }^{8}$ Thus, the task of dealing with the effects of crime coverage has been left to the courts, which have tried to cope with the problem in several ways: by instructing jurors to disregard what they have heard and read before trial and to avoid future contact with material related to the case; by examining prospective jurors about their knowledge of the case and dismissing them when the danger of prejudice is demonstrated; by granting the defendant trial level relief such as a continuance or change of venue; and by reversing convictions where extensive publicity has prejudiced the defendant.

Trial judges commonly instruct the jury to disregard all that they have heard about the case outside the courtroom, ${ }^{9}$ but experienced trial lawyers suggest that such instructions are self-defeating, ${ }^{10}$ and serve only to call a jury's attention to extraneous material. Moreover, there is general agreement that cautionary instructions are totally inadequate to cope with the problems posed by extensive crime coverage. ${ }^{11}$

Prospective jurors may be examined by the court, and in most states by counsel, about their knowledge of the case and the effect of this knowledge on their impartiality. Where it appears that a member of

6 Testimony of Professor Philip B. Kurland before the Subcommittee on Constitutional Rights and Improvements in Judicial Machinery of the Committee on the Judiciary, on S. 290, 89th Cong., 1st Sess. (1965).

7 E.g., Canon 20, Canons of Ethics of the American Bar Association; Massachusetts Guide for the Bar and News Media; Oregon Bar-Press-Broadcasters Joint Statement of Principles, reprinted in Center for the Study of Democratic Institutions, Free Trial vs. A Free Press 34-37 (1965). These "guides" range from the very general (Oregon) to the fairly specific (Massachusetts).

8 The Massachusetts Guide was adopted by 26 daily and 31 weekly papers in the state but has failed dismally in Boston, where none of the big dailies except the Christian Science Monitor adheres to it. In New York, the Times is reputed to have adopted voluntary restraints, but the other daily papers have not. The Washington Post also follows a unilateral publicity policy but the other Washington dailies have not conspicuously restricted their coverage.

9 See cases collected in 23A C.J.S. Criminal Law § 1186 (1961).

10 Justice Jackson has stated: "The naive assumption that prejudicial effects can be overcome by instructions to the jury ... all practicing lawyers know to be unmitigated fiction." Krulewitch v. United States, 336 U.S. 440, 453 (1949) (concurring opinion).

11 See, e.g., C. Jaffe, supra note 2, at 12; Goldfarb, supra note 2, at 822. 
the panel will not be impartial, he may be excused for cause. ${ }^{12}$ However, a recently published study of civil jury cases ${ }^{13}$ reports that voir dire is ineffective in weeding out unfavorable jurors by eliciting information which would bear on a juror's predispositions. ${ }^{14}$ It would seem that many of the weaknesses in civil voir dire are to be found in the questioning of jurors in criminal cases. ${ }^{15}$ But even if voir dire werea more reliable procedure, the present standards for dismissing jurors. for cause make voir dire a weak countermeasure against jury prejudice. Jurors who know something about the cases are not necessarily excluded, and even those who express a "tentative opinion" about the defendant's guilt may be retained if they testify that they are capable of giving the accused a fair hearing: ${ }^{10}$ Since genuine impartiality is unlikely when individuals have formed impressions from publicity, ${ }^{17}$ once a well-publicized defendant has exhausted his limited peremptory challenges, voir dire and challenge for cause would appear to afford insufficient protection against the effects of publicity. ${ }^{18}$

Trial courts presently have three discretionary remedies at their disposal to protect the defendant from having his case tried at an inappropriate time or place: change of venue, continuance, and declaration of a mistrial. A change of venue transfers the case to another part of the jurisdiction, away from the influence of local publicity and strong feelings in the community where the crime occurred. ${ }^{19} \mathrm{~A}$ continuance post-

12 See, e.g., Reynolds v. United States, 98 U.S. 145 (1878).

13 Broeder, Voir Dire Examinations: An Empirical Study, 38 So. CaL. L. REv. 503 (1965). The data were part of the findings of the University of Chicago Jury Project. Additional findings of the study are presented in Zeisez \& Kalven, The AMERiGan JuRY (to be published in 1966), and in Simon, THE JURY ANd THE DEFense of INSANITY (to be published in 1966).

14 Broeder, supra note 13 , at 505 . A number of factors contributed to the ineffectiveness. of the voir dire: judges were hostile to lengthy examinations, questions were avoided which might have offended potential jurors, and in many cases jurors consciously concealed facts and exhibited a general lack of candor in their answers. Id. at 505-06. It has. also been suggested that examination of the jury is self-defeating in a publicized case, because in order to ask prospective jurors whether they have been exposed to particular information, counsel must come very close to telling the jury precisely that information. Goldfarb, supra note 2, at 821 .

15 While it is probable that judicial hostility to lengthy examinations would not be important in criminal cases, the other factors mentioned in note 14 seem to apply equally in civil and criminal cases.

16 See Irvin v. Dowd, 366 U.S. 717 (1961); Bearden v. United States, 304 F.2d 532 (5th Gir. 1962).

17 See Krech \& Crutchfield, Theory and Problems of Soclal Psychology 86-87 (1948). If the initial impact of pretrial publicity is as great as is supposed, even sequestration of the jury becomes an empty gesture where jurors have been exposed to large amounts of publicity.

18 C. Jaffe, supra note 2, at 12.

19 See Stroud v. United States, 251 U.S. 15 (1914); People v. McKay, 37 Cal. 2d 792, 236 P.2d 145 (1951); People v. Sleezer, 9 Ill. 2d 57, 136 N.E.2d 808 (1956). 
pones the trial and provides a period during which the effects of publicity can subside. ${ }^{20}$ The declaration of a mistrial nullifies a trial in progress and makes possible the continuance or transfer of the case.

Empirical data are not available upon which to base generalizations about trial court standards for granting relief on the ground of prejudicial publicity. It has been said that "trial courts are extremely reluctant to grant changes of venue," 21 and several notorious denials of trial level relief are to be found in the case law on publicity prejudice. ${ }^{22}$ Thus, a principal criticism of the available trial level remedies has been that they are seldom utilized..$^{23}$ A possible explanation is that the judge's decision to grant relief implies that the defendant cannot receive a fair trial in his court, and it is natural for judges to have confidence in their own ability to assure fair trials. Furthermore, since little is known about the effects of crime coverage on trials, the judge is generally without a standard to evaluate a defendant's motion. ${ }^{24}$ A second criticism of the present system is that because the granting of relief is almost wholly within the trial court's discretion, different defendants receive different treatment even within the same jurisdiction. For these reasons, it is generally agreed that the present utilization of trial level remedies is insufficient to cope with the problems posed by extensive crime coverage. ${ }^{25}$

A victim of publicity who is not granted trial level relief may appeal his conviction on the ground that the refusal of such relief denied him a fair trial. Such appeals will succeed where the defendant can show either that publicity about his case resulted in "actual prejudice" by exposing the jury to damaging material which would not have been admissible as evidence against the accused or that publicity probably so influenced the community where the accused was tried that a fair trial could not have taken place. ${ }^{26}$

20 See Thompson, The Law Relating to Prejudicial News Reporting in Criminal Cases, in Conference on Prejumicial News Reporting in Criminal Cases 7, 14-15 (Inbau \& Botter eds. 1964).

21 Id. at 13.

22 See, e.g., Irvin v. Dowd, 366 U.S. 717 (1961); Sheppard v. Maxwell, 346 F.2d 707 (6th Cir.), cert. granted, 86 Sup. Ct. 289 (1965); Singer v. State, 109 So. 2 d 7 (Fla. 1959).

23 Inbau \& Sowle, Cases on CrIminal Justice 1092 (2d ed. 1964); Will, Free Press $v$. Fair Trial, 12 DE PAUL L. REv. 197, 209 (1963).

$24 \mathrm{Cf}$. Thompson, supra note 20, at 13. There are a few objective standards of limited application to aid the judge: television coverage of court proceedings seems to be prohibited by Estes v. Texas, 381 U.S. 532 (1965). But see id. at 587 (Harlan, J., concurring). Jurors who admit to a definite bias are excused for cause and trials must be continued or transferred when it is impossible to find a full panel of jurors willing to state that they will give the defendant a fair trial. See Irvin v. Dowd, 366 U.S. 717 (1961).

25 Goldfarb, supra note 2, at 818-24; C. Jaffe, supra note 2, at 17; L. Jaffe, supra note 5, at 517-19.

26 Rideau v. Louisiana, 373 U.S. 723 (1963) (probable prejudice); Irvin v. Dowd, 366 U.S. 717 (1961) (actual prejudice). 
Under the first test, a defendant must show that crime coverage exposed jurors to inadmissible material either before or during the trial. ${ }^{27}$ If the exposure took place before the trial, the appellate court will usually place great weight on the examination of jurors in determining whether the defendant was prejudiced. ${ }^{28}$ If the inadmissible material was published after the trial began, the key questions are whether any members of the jury actually read it and if so, whether this might have affected the impartiality of the jury. ${ }^{29}$ The difficulty of proving actual prejudice means that this standard will afford relief to few injured defendants.

Two recent Supreme Court decisions adopting the second test dispensed with the usual requirement that the defendant demonstrate "actual prejudice" and held that convictions should be reversed where the circumstances justify a presumption of prejudice from publicity. Rideau v. Louisiana ${ }^{30}$ reversed a conviction where the defendant's confession was repeatedly televised prior to trial, and Estes v. Texas ${ }^{31}$ extended this principle to prohibit the televising of the trial itself. The new rule of Rideau and Estes holds out more promise of relief for publicized defendants, but standards for applying the rule remain to be devised. The failure to devise clear standards also means that those newspapers concerned with the prompt conviction of criminals will probably not be deterred from publishing news items before and during criminal trials by the possibility that this will cause convictions to be reversed. Were the courts to set up clear prohibitions or guidelines for reversal of publicity cases, such as a flat prohibition of televising trial proceedings, the certainty of reversal where such rules were violated might cause the mass media to refrain from publishing objectionable material. But it is unlikely that many forms of potentially dangerous publicity could ever be categorized in terms of clear rules where constitutional standards of fair trial are the basis for classification. ${ }^{32}$

27 Irvin v. Dowd, 366 U.S. 717 (1961) (before trial); Marshall v. United States, 360 U.S. 310 (1958) (during trial); United States ex rel. Bloeth v. Denno, 313 F.2d 364 (2d Cir. 1963) (before trial).

28 See, e.g., United States ex rel. Bloeth v. Denno, 313 F.2d 364 (2d Gir. 1963).

29 Marshall v. United States, 360 U.S. 310 (1958); cf. Janko v. United States, 281 F.2d 156 (8th Cir. 1960), rev'd per curiam, 366 U.S. 716 (1961).

30373 U.S. 723 (1963).

31381 U.S. 532 (1965). But see id. at 587 (Harlan, J., concurring).

32 Some types of crime coverage are susceptible of precise categorization which could be used by courts in applying constitutional doctrine. The courts could, for example, conclude that any time a defendant's criminal record or the incriminating results of a "lie detector" test have been publicized, the prejudicial effect of such publicity renders the denial of trial level relief a deprivation of a defendant's constitutional right to a fair trial. However, the prejudice resulting from publication of other matters may depend on 
Finally, relying on reversal as the sole answer to the problems posed by crime coverage involves a great cost to the defendant and the community. By the time a criminal conviction is reviewed, society has already borne the expense of, and has subjected the defendant to the ordeal of, a public trial. A solution should be sought which avoids useless trials.

\section{Recent Proposals}

The recognition that present remedies are not adequately forestalling the threat of prejudicial publicity has produced a number of proposals, four of which have received considerable attention: the Attorney General's directive limiting the release of information by Justice Department personnel, ${ }^{33}$ Senator Morse's bill which would punish the divulgence of information relating to pending criminal litigation in the federal courts, ${ }^{34}$ the proposed Massachusetts statute which would regulate the release and publication of information about pending criminal trials, ${ }^{35}$ and Professor Jaffe's recommendation to regulate publication of information related to pending criminal trials. ${ }^{36}$ Each of these proposals has certain shortcomings which the approach suggested in this comment attempts to overcome.

\section{The Attorney General's Directive}

On April 16, 1965, the Attorney General issued a directive to Justice Department employees setting out guidelines for the release of information relating to criminal proceedings. It advised against the release of five kinds of information:

(i) Observations about a defendant's character.

(ii) Statements, admissions, confessions, or alibis attributable to a defendant.

(iii) References to investigative procedures, such as fingerprints, polygraph examinations, ballistic tests, or laboratory tests.

the circumstances of a particular case. This is probably true with disclosures regarding the circumstances of arrest, the nature of the crime, and the possible involvement of the defendant in other crimes, as well as with the total amount of crime coverage in all forms. It is therefore not surprising that appellate courts are unwilling to upset criminal convictions and repudiate a trial court's exercise of discretion except where the effect of publicity is extreme.

33 Release of Information by Personnel of the Department of Justice Relating to Criminal Proceedings, 28 C.F.R. $\S 50.2$ (1965) [hereinafter cited as Directive].

34 S. 290, 89th Cong., 1st Sess. (1965).

35 Mass. H.B. 3991 (1965). This bill has been tabled pending the results of a study authorized by the legislature on October 5, 1965. See Mass. Acts \& Resolves of 1965, ch. 119 , at $42-43$.

36 L. Jaffe, supra note 5, at 528-24. 
(iv) Statements concerning the identity, credibility, or testimony of prospective witnesses.

(v) Statements concerning evidence or argument in the case, whether or not it is anticipated that such evidence or argument will be used at trial. ${ }^{37}$

The directive further advised against the encouragement or assistance of news media "in photographing or televising a defendant or accused person ... in federal custody." 38 These guidelines derive from the recognition that release of this kind of information can "create dangers of prejudice without serving a significant law enforcement function." ${ }^{3}$ But the directive is, at best, a partial answer to the problems attributable to extensive crime coverage. It applies only to Justice Department employees; where local authorities participate in investigations, they are free to provide the press with the prohibited types of information. The directive does not apply to the release of information about a suspect who is a fugitive from justice. ${ }^{40}$ Further, it is expressly subordinate to the discretion of the responsible Justice Department representative on the scene. ${ }^{41}$ More importantly, such a policy cannot regulate the flow of prejudicial information to the mass media. Even if all prosecuting offices were to follow the lead of the Justice Department, information could still be obtained from witnesses, public records, police, and victims. ${ }^{42}$ Because this directive applies only to the Justice Department and controls only the flow of certain types of prejudicial publicity, it may diminish the crime coverage problem but does not eliminate it.

\section{The Morse Proposal}

On January 6, 1965, Senator Wayne Morse introduced a bill "To protect the integrity of the court and jury functions in [federal] criminal cases." 43 The bill provides:

It shall constitute a contempt of court for any employee of the United States, or for any defendant or his attorney or the agent of either, to furnish or make available for publication

37 Directive $\$ 6$.

38 Directive $\$ 7$.

39 Directive $\$ 6$.

40 Directive $\$ 8$.

41 Directive $\$ 9$.

42 For example, criminal records are "public record." Directive $\$ 4$.

43 S. 290, 89th Cong., 1st Sess. (1965). The bill is co-sponsored by fifteen senators, and has been endorsed by the Judicial Conference of the United States. Judicial Conference of the United States, Report of Proceedings, March 18-19, 1965, p. 21. 
information not already properly filed with the court which might affect the outcome of any pending criminal litigation, except evidence that has already been admitted at the trial.44

The bill would punish contempt by a fine not exceeding $\$ 1,000 .^{45}$

While more comprehensive in coverage than the Attorney General's directive, the bill attaches no penalties to the publication of crime news and fails to protect defendants from the publication of witnesses' opinions, criminal records, or details of the alleged crime, or from the damage which can result from a one-sided presentation of evidence offered in court. Like the Attorney General's directive and other attempts to control the divulgence of information to the mass media, the Morse bill does not provide adequate protection against the effects of crime coverage because it cannot regulate all the sources of prejudicial publicity and because it does not afford relief to the accused when his case has already received excessive publicity.

\section{The Massachusetts Proposal}

A more comprehensive attempt to regulate the release of information relating to pending criminal cases is the proposed section 39 of chapter 268 of the General Laws of Massachusetts, ${ }^{46}$ entitled, "An Act protecting trial by jury from influence by the divulgence, broadcast or publication of certain information." It provides that:

Any statement or information ... shall be deemed to be prejudicial to a defendant's right to a fair and impartial trial by jury if it relates (a) that any person has confessed to a crime; or (b) the contents of any confession or part thereof; or (c) that any person arrested for having committed a crime has ever committed, been suspected of, accused of, arrested for, indicted for [,] convicted of or acquitted of the commission of any other crime; or (d) transcripts, reports or summaries of occurrences taking place during the course of proceedings from which the jury has been excluded by the trial court. ${ }^{47}$

The proposal provides that no officer of the court shall divulge such "prejudicial" information to a news disseminating agency and that no

44 Ibid.

45 Ibid.

46 Mass. H.B. 3991 (1965). A number of commentators have proposed similar broad regulations patterned after the British use of the contempt power to control crime coverage. See, e.g., C. Jaffe, The Press and the Oppressed-A Study of Prejudicial News Reporting in Criminal Cases (II), J. CRIM. L., C. \& P.S. 158 (1965); McCarthy, supra note 1, at 94; Comment, Contempt by Publication, 60 Nw. U.L. Rev. 531 (1965).

47 Mass. H.B. 3991, § 2 (1965). 
news disseminating agency shall publish or broadcast any statement or information classified as "prejudicial." 48

One draft of the bill would treat a violation as a contempt of the court which has trial jurisdiction over the criminal proceedings, with the proviso that trial by jury be available in prosecutions under the statute. ${ }^{49}$ A second draft would make violation a misdemeanor. ${ }^{50}$

The Massachusetts proposal affords much broader protection than regulations which do not control the publication of crime news. It has often been suggested that such a program is the only workable alternative to the dangers of extensive crime coverage. ${ }^{51}$ But this proposal, too, would fail to afford the subject of publicity complete protection from such potentially prejudicial forms of publicity as the one-sided presentation of material presented at the trial and saturation coverage of a criminal trial. In addition, because the proposed statute would constitute a direct restraint on the liberty to divulge and publish information and opinions, it may be invalid as a violation of first amendment freedom of the press. In the twenty-five years since the present standards were announced for contempt by publication, the Supreme Court has not upheld a contempt citation punishing publication. The rule that a publication is punishable by contempt only if it posed a "clear and present danger" to the integrity of the judicial process has resulted in the reversal of contempt citations where newspapers attacked judges. ${ }^{52}$ The Court's recent decision in New York Times Co. v. Sullivan, ${ }^{53}$ reversing a state court libel judgment on first amendment grounds, strongly indicates that the Supreme Court is not about to relax the standards which limit the state's right to abridge free expression. ${ }^{54}$

On the other hand, the constitutional limitations on the use of the contempt power have never been applied to situations involving a pending jury trial, and the Supreme Court has never passed on a case

48 Mass. H.B. 3991, \& 1 (1965).

49 Mass. H.B. 3991, $\S \S 5,6$ (1965).

50 Mass. H.B. 4201 (1965). Professor Jaffe feels that divorcing the regulation of crime coverage from the contempt power may make such a proposal less objectionable to the courts. See L. Jaffe, supra note 5 , at 523.

51 See C. Jaffe, supra note 46 , at 165.

52 The leading case is Bridges v. California, 314 U.S. 252 (1941). See also Wood v. Georgia, 370 U.S. 375 (1962); Craig v. Harney, 331 U.S. 367 (1947); Pennekamp v. Florida, 328 U.S. 331 (1946). In all four cases the Court reversed state court contempt convictions.

53376 U.S. 254 (1964).

54 Professor Kalven maintains that "the contempt problem is at least a sibling if not a twin to the one presented in the Times case." Kalven, The New York Times Case: A Note on "The Central Meaning of the First Amendment," 1964 SUPREME COURT REv. 191, 214. 
where the legislature had explicitly declared particular practices to be dangerously prejudicial. ${ }^{55}$ Thus, within the framework of precedent the Court could allow some use of criminal penalties to regulate publicity regarding pending jury trials. 56

Whatever the legal status of the Massachusetts approach, to the extent that regulation of this sort limits free expression, it is to be regretted. The danger exists that it might set a precedent for more general regulation of free expression. But even if this approach can be limited to the area of its inception, such restraint undermines the desirable effect upon the community of some kinds of criminal publicity. As the Scottsboro case indicates, ${ }^{57}$ an imperfect judicial system has frequently required the corrective effects of public arousal. Public pressure can also be a powerful weapon against corruption when the prosecutor or the police fail to enforce the law. ${ }^{58}$ Furthermore, in unusual circumstances pretrial publicity can serve to reduce community anxiety. ${ }^{59}$ Imposing substantial restraints on publishers would give insufficient respect to the legitimate public concern with crime problems.

Finally, the Massachusetts proposal does not reach such potentially prejudicial coverage as media treatment of the facts of the crime, the circumstances of arrest, and contemporaneous coverage of the events and evidence presented at trial.

In sum, the Massachusetts proposal raises a serious constitutional question and would limit freedom of expression. It would also tend to reduce the effectiveness of publicity in safeguarding against prosecutor and police corruption and in alleviating community anxiety. And because it fails to regulate many forms of crime coverage, it does not even fully protect the defendant from the threat of prejudice.

55 See Wood v. Georgia, 370 U.S. 375, 389 (1962); Cantwell v. Connecticut, 310 U.S. 296 (1940).

56 The Supreme Judicial Court of Massachusetts considered this question and found itself "unable to predict what might be held in the Supreme Court of the United States. ..." Opinion of the Justices, 208 N.E.2d 240, 244 (Mass. 1965).

57 Nine young Negroes were convicted of rape, a capital offense in Alabama. The case reached the Supreme Court in Powell v. Alabama, 287 U.S. 45 (1932). Ultimately, northern public opinion saved the defendants from the electric chair. See REynolds, CourTroom 240304 (1950).

68 L. Jaffe, Trial by Newspaper, 40 N.Y.U.L. REv. 504, 512 (1965).

50 For example, if a suspect were to confess to the recent epidemic of Boston stranglings, the publication of such information would serve this sort of public interest. For a graphic example of an unsolved crime arousing anxiety in the community where it occurred, see CAPOTE, IN CoLD BLOOD (1966). Unfortunately, publishing information which is most likely to prejudice an accused (e.g., publication of a confession or an official's belief that the accused is guilty) seems to be the most effective way to reduce community anxiety. 


\section{The Jaffe Proposal}

In a recent article, ${ }^{60}$ Professor Louis Jaffe recommended a more refined penal regulation of mass media crime coverage. He believes that laws prohibiting very narrow classes of pretrial publicity and a general prohibition of publicity during the trial would probably be sustained by the courts but that general prohibitions of pretrial publicity would violate present first amendment standards. ${ }^{61}$ He therefore proposes: (a) that the divulging of information bearing upon the guilt or innocence or character of an accused by attorneys, police, or other public officials be punishable as contempt of court;" and (b) "from the beginning of the voir dire until the rendering of the verdict, it should be made a crime to publish a confession, information bearing upon guilt or innocence or upon the character of the accused, unless and until such matter is admitted into evidence."63

The limited effect of prohibiting public officials and officers of the court from divulging information has already been discussed. Thus, the Jaffe proposal leaves the burden of protecting publicized defendants on the prohibition of certain kinds of crime coverage during the trial and voir dire. Much depends upon how broadly the clause relating to material "bearing on guilt . . . or character" is interpreted. A broad interpretation would result in a virtual publicity blackout during trial; a narrow reading would invite fine distinctions and limited protection.

In either case, it can be said that the Jaffe proposal avoids many of the objections raised against the Massachusetts proposal. ${ }^{.4}$ Its ample allowance for pre- and post-trial publicity would seem sufficient for the beneficial functions of crime coverage to operate. ${ }^{65}$ Whether such regulation would in fact be upheld by the Supreme Court cannot be predicted, but this limited program would surely be more acceptable than a general prohibition of crime coverage prior to the rendition of a final judgment.

This greater acceptability is achieved at a high cost. No provision is made for relief for victims of publicity; they are, presumably, in no better position under the Jaffe proposal than under present law once publication occurs. More importantly, the proposal does not limit pre-

\footnotetext{
60 L. Jaffe, supra note 58 , at 504.

$61 \mathrm{Id}$. at 522.

62 Id. at 523-24.

63 Id. at 524.

64 Professor Jaffe feels that his proposal's acceptability is also enhanced by its substitution of conventional criminal regulation for an extension of the contempt power. Id. at 523 .

65 Id. at 512.
} 
trial publicity, but trusts the present voir dire system to provide comprehensive protection against the effects of pretrial publicity upon potential jurors. Yet it has been suggested that voir dire is an ineffective screening mechanism and that the present standards of juror challenge do not protect an accused from the prejudicial effects of crime coverage. ${ }^{66}$

Thus, the Jaffe proposal is but another partial solution to the crime coverage problem. Whether such partial protection justifies the imposition of criminal sanctions on the press is a question best postponed until more is known about the magnitude of the publicity problem in America.

\section{A New Approach: Automatic Defendant-Centered Remedies}

Assuming that something must be done to control the impact of crime coverage on criminal trials and that an alternative to direct press censorship should be sought to avoid infringing on the freedom to publish, an appropriate first step in the development of a comprehensive policy might lie in the establishment of automatic standards for granting trial level relief to the publicized defendant. The defendantcentered remedies previously discussed-the challenging of jurors for cause and the granting of motions for change of venue, continuance, and new trial-were found to be inadequate at present because they are seldom used and because of the uncertainty and inconsistency involved whenever protection depends on trial court discretion. These weaknesses indicate that the present system fails to protect publicity victims and does not deter the mass media from excessively publicizing criminal cases.

The above shortcomings are not inherent in a system of defendantcentered remedies. A statute or judge-made rule could set out the conditions upon which a defendant would be entitled to trial level relief as a matter of right. ${ }^{67}$ At the same time, the standards of juror

66 See discussion accompanying notes 13-18 supra.

67 Rules 18 and 21 of the Federal Rules of Criminal Procedure would seem to confer upon federal district courts the power to implement this kind of policy. See Rule 6 of the Rules of the United States District Court for the District of Oregon (1964) for a local court rule governing the place of trial. The United States Supreme Court could establish automatic standards for federal courts by rule with the approval of Congress and probably without congressional mandate by judicial decision. The inherent rule-making power of the state courts would support the establishment of such a policy by supreme courts or conferences of trial level judges unless the automatic policy conflicted with existing statutes. Rule-of-court policy would evidently be allowed, for example, in California. See People v. Walker, 76 Cal. App. 192, 244 Pac. 94 (1926); cases collected at 13 CAL. Jur. 2D Courts $\S 169$ (1954). 
challenge could be liberalized in cases involving extensive crime coverage. ${ }^{88}$ Such a rule could specify that when publicity is extensive but insufficient for mandatory relief, requests for relief should be granted when this would not involve substantial costs in terms of time, money, and convenience. If the kind or amount of publicity exceeded the threshold before the date of trial, a change of venue, extended continuance, or both, would be granted as a matter of right. If the threshold were exceeded during the trial, a mistrial would be granted

68 A more liberal standard for challenging jurors on the basis of prejudice would apply to all criminal cases. But suggested alternatives to the present rules, such as excusing potential jurors who have formed tentative opinions or excusing all jurors who have read or heard about the case, would normally affect only those criminal cases involving substantial publicity. Whether it is preferable to exclude all potential jurors who have heard about the case or only those who express "tentative opinions" depends on one's view of the efficacy of voir dire and on the possibility of finding totally uninformed juries in well publicized cases. To the extent that voir dire is considered unreliable, the broader exclusion is to be preferred. This would seem to be the implication in Broeder, Voir Dire Examinations: An Empirical Study, 38 So. CAL. L. REv. 503 (1965). However, little would be gained by promulgating a jury standard so strict that in some cases no jury could be impaneled. Therefore, while present standards are in need of reform, much empirical research is needed to determine the extent to which a reform of the standards for juror challenge is practical. In theory, a standard that allowed challenge of any juror who admitted knowledge of a particular case could be a complete remedy to the crime coverage problem. Such a program, however, would impanel only the ill-informed or untruthful juror, and might do more harm than good.

Another suggested reform is the selection of jurors on the basis of intelligence and educational background or "a psychological test designed to gauge the individual's resistance to propaganda." Comment, The Impartial Jury-Twentieth Century Dilemma: Some Solutions to the Conflict Between Free Press and Fair Trial, 51 CoRNeul L.Q. 306, 326 (1966). However, there is insufficient correlation between intelligence and education and the tendency to be affected by publicity to justify reliance on such standards as a sufficient guard against prejudice. See ibid.

A psychological test based on a propaganda scale would be inadequate. First, tests would not measure the extent to which each individual was actually exposed to publicity about the case, but would leave this task to the untrustworthy voir dire procedure. Present standards which allow individuals with tentative opinions to sit on the jury, and thus jeopardize the publicized defendant, would remain unchanged. Second, such tests would measure only the effects that presenting material in different forms will have upon individuals; they cannot measure the impact information will have on individuals irrespective of its source or format. Convincing evidence pointing to a defendant's guilt which may be the subject of publicity, such as inadmissible real evidence, confessions obtained in violation of strict constitutional standards, the previous criminal record of the accused, and the testimony of witnesses unavailable to testify at the trial, will influence individuals' opinions independently of the variable tested by the propaganda scale. Thus, the danger of prejudice would remain even if such tests predicted perfectly the traits they were designed to measure.

Also, under this scheme the jury would still be exposed to extensive publicity even if they were not as profoundly affected by some of it as their peers would be, and nothing would be done to offset the effect upon judges and juries of pressures from a community aroused by publicity. 
as of right and appropriate venue and time adjustments would be made respecting the new trial. ${ }^{69}$ A refusal to grant the relief specified by the rule would constitute reversible error.

The greatest difficulty with this approach involves establishing the standards for automatic relief. The paucity of empirical data on the effects of publicity renders any judgment arbitrary. Modest research, such as a study of the amount of crime coverage in metropolitan newspapers and the number of cases accorded different amounts of publicity during a given period, would be valuable. ${ }^{70}$ In the absence of such information, it is suggested that the standards for automatic relief should have both a qualitative and a quantitative dimension. Qualitative standards would deal with those kinds of publicity which may pose a special threat to fair trials, such as information which is generally excluded from criminal litigation. The statute or court rule would set out the specific kinds of information which when publicized would qualify a defendant for automatic relief, regardless of the extent of coverage they received. Previous criminal records, confessions, and evidence of the defendant's bad reputation would certainly be included in the qualitative standard. ${ }^{71}$ Other kinds of material, such as editorial

69 In the case of pretrial publicity a defendant who did not timely request appropriate relief and could not show a good reason for his failure to do so would presumably be held to have waived the relief to which he would otherwise be entitled.

70 Reliable information about the number of cases that involve extensive publicity would also yield vital information about the relative cost of publicity remedies. The primary cost of defendant-centered remedies would be the extra time and money society must invest in each case that would be affected by the policy. The total cost of such relief would depend on the number of cases affected: if the number of extensive publicity cases is small, the cost of defendant-centered remedies will be correspondingly small and the legal system will be able to afford a generous attitude toward publicized defendants.

The primary cost of proposals that call for restrictions on the press and on the public right to information is the loss of the freedom to publish. The nature of this restraint is much more important in determining its cost than the number of times restraint would have to be employed. Thus, a finding that relatively few cases are involved would weigh in favor of the defendant-centered solution; by the same token, a finding that the number of cases affected is very large would tend to favor the adoption of restraints.

71 Certain kinds of evidence which are usually excluded from criminal trials may be admitted in special situations. Evidence of prior criminal convictions, for example, is excluded when offered to prove the defendant's criminal disposition, but is admitted when it bears on the defendant's motive. See, e.g., Fuller v. State, 269 Ala. 312, 334-37, 113 So. 2d 153, 172-76 (1959), cert. denied, 361 U.S. 936 (1960). In a situation of this kind, pretrial publication of such material should qualify a defendant for automatic relief even if the evidence might have been admitted at his trial. This approach should be employed where the general policy excluding such evidence is based on its prejudicial effect, because only such a rule can give the media clear warning about the effect of publishing information in this category, and because allowing publication would expose the defendant to the prejudicial effect of such evidence without the benefit of a limiting instruction and a court's admonition to reject the prejudicial inference. 
comment on the case, opinions of prospective witnesses, and extended official comments, could be also included. ${ }^{72}$

Quantitative standards could be based on the amount of publicity concerning a particular case or the impact of that publicity on community opinion. A given amount of publicity, such as five hundred column inches of newspaper coverage in the twelve months before trial, would automatically entitle a defendant to pretrial relief. An adaptation of this general policy to less populous areas would utilize a percentage, as opposed to an absolute amount, of total newspaper coverage devoted to one criminal case over a given period of time. This would compensate for the lesser number of newspaper pages printed in such areas. Newspaper coverage would be used as a measurement because it is readily quantified and it probably reflects coverage in the other media. ${ }^{73}$

Setting an arbitrary level of publicity as the standard need not impose a hardship on those defendants who do not qualify for automatic relief. The more liberal discretionary relief called for by the policy embodied in the new statute, court rule, or decision, coupled with automatic relief when certain kinds of material are published without re-

72 For a proposal which would lead to automatic relief when editorial comment is directed at an accused, see Brief for the American Civil Liberties Union as Amicus Curiae, p. 27, Sheppard v. Maxwell, cert. granted, 86 Sup. Ct. 289 (1965).

73 The amount of coverage which qualifies a defendant for quantitative relief would be set arbitrarily at the start. No information available suggests the quantity of press coverage-fifty, or five hundred column inches-with which a substantial danger of prejudice is associated. Initially, the threshold would be very high (e.g., 500 column inches) and would afford protection only in extreme cases. The danger of publicity prejudice would seem substantial in cases which receive 500 column inches of newspaper coverage, the equivalent of twelve one-half page stories in a large city newspaper with the format of the Chicago Sun-Times. Coverage so extensive is a response to community interest that editors must think already exists as well as a powerful means of increasing interest and influencing attitudes. Also, when newspapers in a community have covered a story this thoroughly, competition will normally impel other media to add to the exposure of a case.

Setting the cutoff point this high in no way suggests that less extensive publicity may not involve the same danger of an unfair trial. The qualitative standards and quantitative standards based on public opinion polls will afford protection to many of these defendants. Because of this supplemental protection, and because some threshold must initially be set, it should be set at a level of publicity sufficiently high that a prejudicial impact can be presumed to exist. However, after the policy has been in effect for a time the sufficiency of the protection afforded by the original standard could be evaluated in terms of the number of cases in which public opinion poll data suggest that prejudice exists. If many such cases were those in which the amount of publicity was insufficient for automatic protection, the threshold would be lowered.

Because the quantitative standard would give some additional protection to publicized defendants yet would involve remedies already within the judge's discretion, the arbitrary figure selected initially would not be palpably objectionable. But a recognition that such a threshold is without an empirical foundation should encourage liberal discretionary relief and a readiness to change the standard whenever this appears appropriate. 
gard to quantity, represent a significant improvement over a defendant's present plight. Further protection might come from the application of a second quantitative standard: at the direction of the court, modest public opinion polls could provide a supplementary criterion for granting relief. When polls revealed that more than a set percentage of the local population sample expressed belief in the defendant's guilt, relief would issue automatically. Once techniques and samples for a locality were established, such polls would not involve great expense, and they would constitute an adequate foundation for defendant-centered remedies which would not involve great sacrifices of other values such as judicial economy or freedom of the press. ${ }^{74}$

A general policy of defendant-centered remedies would be expected to have both corrective and preventive effects on criminal publicity. Corrective effects are the more obvious product: change of venue will usually remove the defendant from the area where the public has been exposed to extensive publicity; continuance will permit publicity effects to recede; liberalized challenge rules will help detect and remove prejudice; new trials will guard against convictions based on prejudice.

The automatic policy might also exert a preventive influence on crime coverage. First, clear standards will give the media objective criteria for pre-judging how much and what kinds of coverage are considered objectionable. Voluntary codes have failed to provide such a standard because they are often impossibly vague and because they carry no weight as official standards. ${ }^{75}$ Clear standards, by making compliance easy and permitting limited forms of coverage, will encourage the cooperative response of the mass media. Second, the fact that publication of material included in the automatic policy will result in the certain delay of criminal justice might motivate professional organizations and police to develop crime coverage policies of their own. Bar

74 An adequate telephone survey for the Chicago area would cost between two and three hundred dollars, representing seventy hours of telephone work for a 500 person survey. Interview with David Segal, National Opinion Research Center, Chicago, Illinois, Oct. 22, 1965. Such a survey would almost certainly be accurate enough to serve as the basis of pretrial procedural relief to a defendant. For example, if a 500 person random survey indicated that 20 per cent of the sample population expressed some belief in the defendant's guilt, 19 times out of 20 this would indicate that between 16 per cent and 24 per cent of the sampled population had this belief. See PARTEN, SurveYs, Polls, AND SAMples 307-30 (1950). This kind of "approximation" seems entirely sufficient for the purposes which opinion polling would serve under an automatic system. A public opinion poll conducted to determine whether relief should be granted in a specific case would probably ask whether individuals had heard of the accused in relation to the crime and whether they had formed any opinion as to the guilt or innocence of the accused.

75 For example, the Oregon Bar-Press Statement of Principles says nothing more specific than "good taste should prevail in the selection, printing and broadcasting of the news" and "no person's reputation should be injured needlessly." 
associations faced with the systematic delay of trials might punish attorneys who disclose information which would violate the qualitative standards in force in their jurisdiction. In addition, attorneys could be encouraged to use the information they are permitted to release to the press as a lever, requiring in exchange for such information that reporters promise that newspaper coverage will not be such as to trigger automatic relief. This would provide an incentive of preferential treatment to those newspapers and radio and television stations which cooperate with the policy. The police administration, greatly interested in swift convictions, could implement a similar policy.

A third factor tending to limit crime coverage under an automatic policy is the implicit threat that if such a policy fails the next logical step is the direct regulation of crime coverage and the resort to criminal penalties for violation. While the policy is designed as a sincere effort to avoid direct regulation, it will serve as a warning that continued abuse will invite a more punitive official publicity policy. Thus, although the defendant-centered system may ultimately present the media with the choice between voluntary and compulsory restraints, it does so without any measure of direct control over freedom of expression.

Finally, it has been suggested that the media themselves have an interest in quick and certain criminal convictions. ${ }^{76}$ While it is doubtful that this factor would have a significant effect on crime coverage if no other negative consequences attached to extensive crime coverage, such a concern might add to the cumulative effect of the other sanctions of the automatic policy.

There are, however, several objections to such a policy which should be noted. It has been argued that publicity effects are so pervasive that changing the county of trial or postponing trial for six months or a year would not suffice to eradicate the prejudice caused by publicity. ${ }^{77}$ This proposition is usually based on such extraordinary situations as the $R u b y$ murder case in Dallas and the Sheppard case in Cleveland.78 But most cases are heavily publicized in relatively circumscribed geographical areas; the regional or national cause celebre is a relative rarity. Even those cases that become widely known are much more thoroughly exposed close to home: the publicity in the Sheppard case,

76 L. Jaffe, supra note 58 , at 522 .

77 See C. Jaffe, The Press and the Oppressed-A Study of Prejudicial News Reporting in Criminal Cases, 56 J. CRIM. L., C. \& P.S. 1, 11 (1965).

78 The appeal in the Sheppard case is reported in State v. Sheppard, 165 Ohio St. 293, 135 N.E.2d 340 (1956). Regarding the Oswald-Ruby publicity, see KAPLAN \& WALTz, The Trial of JAGK RuBY $37,69-90$ (1965). 
for example, seems to have been both more intensive and more sensational in Cleveland than it was in distant Ohio communities. ${ }^{79}$ For this reason, and because the prejudicial effects of publicity diminish with time, ${ }^{80}$ defendant-centered relief is a step in the right direction even in the ususual case. Liberalizing the rules for challenging jurors for cause with respect to publicity would further assist the nationally publicized defendant. Despite these safeguards, a particular defendant might need still further protection; it might even be impossible to afford him a trial by a jury which has not been substantially informed about his case prior to trial. But the rare problem which may be incapable of solution does not diminish the acceptability of this approach in the vast majority of cases, in which it would work effectively.

A second argument against automatic defendant-centered remedies is that they are costly. Change of venue is expensive, notably because of the increased cost of summoning and transporting witnesses and counsel. Continuance represents a cost in terms of time, efficiency, and the decreased likelihood of obtaining the best testimony of witnesses in open court.81 But such a policy would also involve certain savings by avoiding the cost of many of the reversals and new trials which the present system produces as well as the expense involved in impaneling an impartial jury in a community which has been exposed to extensive criminal publicity. The total cost would depend on the threshold selected to trigger automatic relief and upon the number of cases which were extensively publicized.

\section{Conclusion}

The present substantive framework for handling criminal publicity problems is inappropriate to the formulation of a workable general policy. Attempts to limit the divulgence of information about pending criminal litigation by attorneys and government employees can be helpful but are probably insufficient because they fail to protect the accused from a number of forms of potentially prejudicial publicity. On the other hand, regulating directly the publication of crime news by imposing criminal sanctions affords more protection to the accused,

79 See the exhibits used by the court in Sheppard v. Maxwell, 346 F.2d 717 (6th Cir. 1965), which came from Cleveland newspapers.

80 Note, Controlling Press and Radio Influence on Trials, 63 HARv. L. REv. 840, 843 (1950) (effects of propaganda diminish over time); see also Levine \& Murphy, The Learning and Forgetting of Controversial Material, 38 J. Abnormal \& Social Psychology 507 (1943).

81 Thompson, The Law Relating to Prejudicial News Reporting in Criminal Cases, in Conference on Prejudictal News Reporting in Crminal Cases 15 (Inbau \& Botter eds. 1964). 
but at a great cost; and even these programs fail to provide complete protection to the publicized defendant.

A statute or court policy defining situations where defendant-centered relief would automatically be granted would not directly restrain the mass media and could give defendants direct protection from the effects of crime coverage. Additionally, such a policy might reduce prejudicial crime coverage by establishing clear official standards of publicity prejudice, which might lead to self-regulation by the police and members of the bar and would carry the implicit threat of more stringent regulation to the point where the media would hesitate before publishing objectionable material. The hypothesis that government restraint of free expression should be used only as a last resort suggests that this defendant-centered program is the appropriate first step in a general policy aimed at assuring every defendant a fair trial. 